\title{
Organizational Image of the University: Students' Perceptions in Their First Year
}

\author{
Özcan Doğan
}

\begin{abstract}
This descriptive study aimed to find out the students' perceptions of the organizational image of Eskişehir Osmangazi University (ESOGU) at the end of their first academic year in the university campus. The study was carried out at the end of 2015-2016 academic-year. The population includes 1062 students who were studying English preparatory program from six departments, and the sample includes 364 students. The data were collected using "perceived organizational image scale" via Google ${ }^{(c)}$ forms. This Likert type scale (ranges from 1- to 5) has seven dimensions which are (a) quality image, (b) program image, (c) sports image, (d) general outlook and physical infrastructure image, (e) social atmosphere image, (f) entertainment image and (g) accommodation-food image. The reliability co-efficient of organizational image scale is $\mathbf{. 9 4}$. The results showed that the organizational image of the university is at "moderate" level. The highest score was in the quality image and the lowest image was in the entertainment image. No significant difference has been found among the students from different departments. Based on the results, it is suggested that the university must publicise its facilities to the students in order to improve its image. Also, all the students (in their first year and last year of education) in the campus might be asked for their opinions in order to improve the image of institution.
\end{abstract}

Index Terms - Image, organizational image, university image.

\section{INTRODUCTION}

Image is a reflexion of individual emotions and perceptions, so it is difficult to define. Therefore, different people can have different perceptions about the same object and the perception can be manipulated by the other people's comments [1].

When individuals think of an object, a concept, a person or an organization, there emerges a picture about those things in his/her mind [2]. The image is the effect or the picture that has been created in the minds, and sometimes this image can be created intentionally by the organization in order to communicate the important characteristics of that organization to the internal and external shareholders $[3,4]$.

The image is everything that affects the perception of the organization by the target population. Therefore, the perception is what is considered to be the truth by the target population of an organization [5].

The image is the sum of the beliefs, attitudes and the impressions of a person or group about an organization, an object or a person; and this perception can be negative or positive [6].

The term image has been a research subject for public

Manuscript received January 3, 2017; revised May 12, 2017.

Özcan Doğan is with Eskişehir Osmangazi University. Eskişehir, Turkey (e-mail: odogan@ogu.edu.tr). relations, marketing and organizational management. As a result, it is an issue that has been questioned by many researchers. There are different types of image but one of the mostly researched one is the organizational image.

Organizational image is a kind of image created in the minds of internal and external shareholders of an organization. In the formation of this image, organizational performance, the social responsibility projects of the organization and the communication strategies that an organization uses to reach its customers are all effective [7].

The managers need to know the effects of the organization they manage on the other people. In the potential customers' minds, there is an image for an organization and a brand. This image cannot always be positive and correct. However, this image has an effect on the preferences of individuals [6].

Organizational image can be defined as the overall interpretations of the outsiders about an organization [8]. Some of the features of organizational image are that it is an abstract concept, and the perceptions about an organization are already present in the minds [9].

The individuals reach a conclusion by comparing and interpreting the information that they gather from different sources like the commercials, data from friends and the cultural context in which they live. The image constructed by those interpretations can sometimes come out automatically or created by the image makers [9].

Some characteristics of the organization have influences on the creation process of the image. The factors that construct the organizational image are as follows [10]:

1) Being dynamic: the organization must be an entrepreneur which has a flexible structure,

2) Having the sense of collaboration: it must have a sincere and approved structure,

3) Having a sense of operation: it must be wellorganized and effective,

4) Character: it must be an organization that is bound to ethical codes, and has a reputation,

5) Successful: it must be a successful organization both financially and confidentially,

6) Withdrawal: the organization may withdraw in the times of loss.

Another factor that produces an image is not only the quality of the service but also the biases in the society. As Spector [10] indicates the biases may cause some positive or negative ideas in the minds of people about an organization. Those ideas are effective when people make choices.

Organizational image may have different meanings for different groups, as there are lots of different parties in communication with the organization. Therefore, it may have different dimensions like the power of influence, 
recruiting skilled personnel and educating them, having the social and environmental responsibility, financial strength, innovativeness, high quality management and high quality product or service [11].

The organizational image can be positive or negative; and therefore, it can affect the target population. People in the organization, the others who work with this organization, or who are potential customers or employees may be affected by the positive or negative image of an organization.

The image of an organization is created in time by comparing different dimensions of an organization to some others. In the image creation process, positive and negative information about an organization has an effect on the others [12]. As a result, the image may be negative or positive based on the information people gather from the environment.

As it is the picture of an organization in the minds of the target population, the managers need to construct a positive image because if there is a negative image on the target, this would cause decrease in the overall performance of an organization [13].

The organizational image affects the individuals within the organization directly because those individuals want to know which aspects of the organization are attributed to them [8]. Some of this information about the organizational image can strengthen the ties between the individuals and their organization [10].

Although having a positive image in the society may mean that lots of people apply to work in this organization [11] and increase in organizational belonging for the current employees, having negative image may cause that the employees in this organization are ashamed of being in this structure and they have stress and depression [8]. Moreover, working in an organization with a negative image may lead to some thoughts that outsiders think the employees are not talented and competent [14].

It can be stated that organizational image is both and an important concern for the customers and the managers of the organizations. It is important for the customers because they want to have the best product or the service; and it is also important for the managers because they want to impress their customers with prestigious alternatives. Not only the private organizations but also the state owned organizations should have positive image perceptions that would make them the preferred ones among others. The universities in Turkey are state owned, private and foundation owned. In order to study at university, students take an exam every year and they are placed into a department according to the result they have in this examination. The student selection system enables students to choose the best one among the others considering their exam result.

There are some factors that determine the students' choices, and the organizational image is one of them because the previous information can construct the image [12]; the image can be still there before they started the university; and the image can have an effect on the preferences of individuals [6], and people's thoughts can affect the others. As a result, describing this image in the minds is considered to be an important issue to discover. The image of the university has some effects on the students. For example; image has direct influence on the student satisfaction [15], [16]. Because organizational image perception is an important issue both for the customers and the managers, this research was planned to see the students' current image perceptions of the university

There are a few researches about the organizational image of the universities in Turkey. One of them was implemented by Polat [17] on the organizational image of Kocaeli University. The research revealed that the organizational image of the university is at "moderate level." Another study was carried out by Silsüpür [18] aiming to find out the organizational image of Istanbul university by using openended questions about the university. The results of the research showed that the students think that Istanbul University is an organization having roots. Örer [19] examined the organizational image of Kahramanmaraş Sütçü Imam University and the researcher found out that some of the facilities in the university are inadequate, which affects the organizational image perception negatively. Cerit [20] examined the organizational image of Bolu İzzet Baysal University and the researcher chose the students of faculty of education. The results showed that the organizational image of the university showed significant difference in terms of the departments of the students. Şişli and Sevinç [21] conducted a research to find out the students' organizational culture and organizational image perceptions and the relationship between those variables. The study explored the perceptions of the students at state-run and foundation universities. The results showed that the organizational image and the organizational culture perceptions of the students were significantly different in terms of their departments.

ESOGU, situated in Eskişehir, Turkey, is a state-run university, which was founded in 1973. The university serves 29822 undergraduate and graduate students in 10 faculties, 4 vocational schools, 4 institutes [22]. The research was carried out in the Department of Foreign Languages, which serves over 1000 students from different faculties (faculty of architecture and engineering, faculty of education, faculty of administration and economics). Therefore, getting the perceptions of these students is considered to be valuable, as the results would depict diverse perceptions.

\section{METHOD}

\section{A. Participants}

The participants of this study are the students studying English at Foreign Languages Department of ESOGU before they start their bachelor's degree. Although $1062^{1}$ students are enrolled at the department, 364 of them from 6 different departments participated in the study. Table I shows the ratio of the students.

The sample size for this research is considered enough because according the table of Bartlett, Kotrlik, and Higgins [23] on determining the sample size (alpha level ,05) the sample of is 282 people are enough for the population of 1062.

\footnotetext{
${ }^{1}$ The researcher got the number of students from student information module which can be accessed only by the academic staff of the universty.
} 
TABLE I: THE NUMBER AND PERCENTAGE OF THE

\begin{tabular}{lrr}
\multicolumn{3}{c}{ PARTICIPANTS } \\
\hline DEPARTMENT & $\mathrm{F}$ & 5,2 \\
\hline English Language Teaching & 19 & 30,3 \\
Mechanical Engineering & 111 & 7,9 \\
Architecture & 29 & 28,1 \\
Electrical and Electronics Eng. & 103 & 10,4 \\
Computer Engineering & 38 & 17,5 \\
International Relations & 64 & 100 \\
Total & 364 & \\
\hline
\end{tabular}

\section{B. Procedure}

In order to collect data for this study, the researcher had to take two permissions. First one was from the institution and the other one from the researcher who developed the instrument. After getting the permissions, the instrument was adapted so that it could be answered online. Then, the participants were contacted via their e-mail and internal email which runs within the department to reach the students, assign homework and evaluate their work. The students were asked to complete the instrument in one week. The researcher visited the classrooms twice during the lesson breaks in order to remind the students to fill in the form. As the participants answered the instrument, the data were saved in the researcher's Google $\mathbb{C}$ account. Finally, once the deadline for filling the instrument was over, the data were saved and interpreted.

\section{The Instrument}

The instrument used in this study was developed by Polat [17]. It is a Likert type scale (ranges from 1- to 5) and has seven dimensions: (a) quality image, (b) program image, (c) sports image, (d) general outlook and physical infrastructure image, (e). social atmosphere image, (f) entertainment image and (g) accommodation-food image. The measured reliability co-efficient of organizational image scale is .94 for this study.

\section{FINDINGS}

The mean scores of the answers were calculated in order to find out the organizational image perceptions of the students. The results were interpreted according to the intervals as; 1.00-1.79 "considerably low", 1.80-2,59 "low, 2,60-3,39 "moderate", 3,40-4,19 "high", 4.20-5.00 "considerably high".

In order to see if the organizational image of the university is significantly different in terms of the departments of the students, the ANOVA test was applied.

TABLE II. THE ORGANIZATIONAL IMAGE OF ESOGU BASED ON THE STUDENTS' PERCEPTIONS

\begin{tabular}{llc}
\hline FACTORS & $x$ & Std. Dev. \\
Quality image & 3,09 & 0,76 \\
Program image & 2,69 & 0,61 \\
Sports image & 2,76 & 0,94 \\
General outlook and infrastructure & 2,80 & 0,82 \\
Social atmosphere image & 2,90 & 0,92 \\
Entertainment image & 2,28 & 1,02 \\
Accommodation-food image & 2,55 & 0,92 \\
Overall organizational image of the & $\mathbf{2 , 8 1}$ & $\mathbf{0 , 6 6}$ \\
University & & \\
\hline
\end{tabular}

Table II shows the organizational image of the university according to the students' perceptions. According to the perceptions of the students in this study, the organizational image of ESOGU is at "moderate level" $(x=2,81$; ss=,66). In the sub levels of organizational image of the university, the quality image $(x=3,09)$ has the highest score and entertainment image $(x=2,28)$ has the lowest score. The other factors following this factor are as follows: social atmosphere image $(x=2,90)$, general outlook and infrastructure $(x=2,80)$, sports image $(x=2,76)$, program image $(x=2,69)$, accommodation-food image $(x=2,55)$. In order to see if the image perceptions of the students differ significantly in terms of their departments, the ANOVA test was applied. The results of the ANOVA test can be seen in Table III.

TABLE III: THE ANOVA TABLE SHOWING ORGANIZATIONAL IMAGE OF ESOGU BASED ON THE STUDENTS' PERCEPTIONS

\begin{tabular}{|c|c|c|c|c|c|c|}
\hline & & $\begin{array}{l}\text { Sum of } \\
\text { Squares }\end{array}$ & $\mathrm{df}$ & $\begin{array}{l}\text { Mean } \\
\text { Sq. }\end{array}$ & $\mathrm{F}$ & Sig. \\
\hline \multirow{3}{*}{$\begin{array}{l}\text { Quality } \\
\text { Image }\end{array}$} & Between Groups & 2,522 & 5 & ,504 &, 855 &, 511 \\
\hline & Within Groups & 211,146 & 358 &, 590 & & \\
\hline & Total & 213,668 & 363 & & & \\
\hline \multirow{3}{*}{$\begin{array}{l}\text { Program } \\
\text { Image }\end{array}$} & Between Groups & 1,374 & 5 & ,275 &, 717 & ,611 \\
\hline & Within Groups & 137,191 & 358 &, 383 & & \\
\hline & Total & 138,565 & 363 & & & \\
\hline \multirow{3}{*}{$\begin{array}{l}\text { Sports } \\
\text { Image }\end{array}$} & Between Groups & 2,470 & 5 & ,494 &, 552 &, 737 \\
\hline & Within Groups & 320,625 & 358 & ,896 & & \\
\hline & Total & 323,095 & 363 & & & \\
\hline \multirow{3}{*}{$\begin{array}{l}\text { General } \\
\text { outlook and } \\
\text { infrastructu. }\end{array}$} & Between Groups &, 792 & 5 & , 158 & ,231 & ,949 \\
\hline & Within Groups & 245,304 & 358 & 685 & & \\
\hline & Total & 246,096 & 363 & & & \\
\hline \multirow{3}{*}{$\begin{array}{l}\text { Social Atm. } \\
\text { Imgage }\end{array}$} & Between Groups & 2,802 & 5 &, 560 & ,652 & ,660 \\
\hline & Within Groups & 307,773 & 358 &, 860 & & \\
\hline & Total & 310,574 & 363 & & & \\
\hline \multirow{3}{*}{$\begin{array}{l}\text { Entert. } \\
\text { Image }\end{array}$} & Between Groups & 5,224 & 5 & 1,045 & ,992 &, 422 \\
\hline & Within Groups & 377,062 & 358 & 1,053 & & \\
\hline & Total & 382,286 & 363 & & & \\
\hline \multirow{3}{*}{$\begin{array}{l}\text { Acco. - } \\
\text { Food Img. }\end{array}$} & Between Groups & 7,875 & 5 & 1,575 & 1,865 &, 100 \\
\hline & Within Groups & 302,355 & 358 & 845 & & \\
\hline & Total & 310,230 & 363 & & & \\
\hline
\end{tabular}

The students participated in this study are all enrolled to the Department of Foreign Languages to get one-year compulsory English for their academic studies in their departments. According to the ANOVA table, it is seen that there is no significant difference among the students in terms of their departments. This shows that they all possess similar ideas about the overall image of the university.

In order to see the students' perceptions in the factors of the instrument, the mean scores calculated. Table IV shows the distribution of the mean scores in the first factor "quality image."

TABLE IV: DISTRIBUTION OF THE SCORES IN QUALITY IMAGE

\begin{tabular}{lcrr}
\hline DEPARTMENTS & Mean & N & Std. Deviation \\
\hline English Language Teaching & 3,0819 & 19 &, 31392 \\
Mechanical Engineering & 3,0531 & 111 &, 80916 \\
Architecture & 3,0192 & 29 &, 65403 \\
Electrical and Electronics Eng. & 3,2233 & 103 &, 82790 \\
Computer Engineering & 3,0848 & 38 &, 81912 \\
International Relations & 3,0104 & 64 &, 69733 \\
Total & 3,0958 & 364 &, 76721 \\
\hline
\end{tabular}

As Table IV shows the mean scores of the "quality image" is at moderate level $(x=3,09)$. Students from Electrical and Electronics Department have the highest score $(x=3,22)$, and students from Architecture Department and International Relations have the lowest scores $(x=3,01)$ in this factor. 
TABLE V. DISTRIBUTION OF THE SCORES IN PROGRAM IMAGE

\begin{tabular}{lcrr}
\hline DEPARTMENTS & Mean & N & Std. Deviation \\
\hline English Language Teaching & 2,7895 & 19 &, 37972 \\
Mechanical Engineering & 2,6768 & 111 &, 69279 \\
Architecture & 2,6940 & 29 &, 57727 \\
Electrical and Electronics Eng. & 2,7451 & 103 &, 60859 \\
Computer Engineering & 2,7730 & 38 &, 74256 \\
International Relations & 2,5918 & 64 &, 47624 \\
Total & 2,6985 & 364 &, 61784 \\
\hline
\end{tabular}

Table V shows the distribution of the mean scores in the "program image." The mean scores of the "program image" is at moderate level $(x=2,69)$. Students from English Language Department have the highest score $(x=2,78)$, and students from International Relations Department have the lowest score $(x=2,59)$ in this factor. However, the distribution of the scores is nearly similar.

TABLE VI: Distribution OF THE SCORES IN SPORTS IMAGE

\begin{tabular}{lcrr}
\hline DEPARTMENTS & Mean & N & Std. Deviation \\
\hline English Language Teaching & 2,7719 & 19 &, 66715 \\
Mechanical Engineering & 2,7267 & 111 & 1,01424 \\
Architecture & 2,9195 & 29 &, 70517 \\
Electrical and Electronics Eng. & 2,7282 & 103 &, 98214 \\
Computer Engineering & 2,9386 & 38 & 1,02478 \\
International Relations & 2,6927 & 64 &, 87550 \\
Total & 2,7610 & 364 &, 94343 \\
\hline
\end{tabular}

Table VI shows the distribution of the mean scores in the "sports image." The mean scores of the "sports image" is at moderate level $(x=2,76)$. Students from Computer Engineering Department have the highest score $(x=2,93)$, and students from International Relations Department have the lowest score $(x=2,69)$ in this factor.

TABLE VII: DiSTRIBUTION OF THE SCORES IN GENERAL OUTLOOK AND

\begin{tabular}{lcrr}
\multicolumn{4}{c}{ INFRASTRUCTURE IMAGE } \\
\hline DEPARTMENTS & Mean & N & Std. Deviation \\
\hline English Language Teaching & 2,8246 & 19 &, 54567 \\
Mechanical Engineering & 2,7988 & 111 &, 82453 \\
Architecture & 2,7184 & 29 &, 64103 \\
Electrical and Electronics Eng. & 2,8673 & 103 &, 90429 \\
Computer Engineering & 2,7456 & 38 &, 93299 \\
International Relations & 2,7839 & 64 &, 77703 \\
Total & 2,8049 & 364 &, 82338 \\
\hline
\end{tabular}

Table VII shows the distribution of the mean scores in the "general outlook and infrastructure image." The mean scores of this factor is at moderate level $(x=2,80)$. Students from Electrical and Electronics Engineering Department have the highest score $(x=2,86)$, and students from Architecture Department have the lowest score $(x=2,71)$ in this factor.

TABLE VIII: DISTRIBUTION OF THE SCORES IN SOCIAL ATMOSPHERE

\begin{tabular}{lcrr}
\multicolumn{4}{c}{ IMAGE } \\
\hline DEPARTMENTS & Mean & N & Std. Deviation \\
\hline English Language Teaching & 3,0526 & 19 &, 60426 \\
Mechanical Engineering & 2,8716 & 111 & 1,00615 \\
Architecture & 2,9224 & 29 &, 76211 \\
Electrical and Electronics Eng. & 2,9951 & 103 &, 93932 \\
Computer Engineering & 2,9342 & 38 &, 96157 \\
International Relations & 2,7578 & 64 &, 88525 \\
Total & 2,9066 & 364 &, 92497 \\
\hline
\end{tabular}

Table VIII shows the distribution of the mean scores in the "social atmosphere image." The mean scores of the "social atmosphere image" is at moderate level $(x=2,90)$.
Students from English Language Department have the highest score $(x=3,05)$, and students from Architecture Department have the lowest score $(x=2,71)$ in this factor.

\begin{tabular}{lcrr}
\multicolumn{3}{l}{ TABLE IX: DISTRIBUTION OF THE SCORES IN ENTERTAINMENT IMAGE } \\
\hline DEPARTMENTS & Mean & N & Std. Deviation \\
\hline English Language Teaching & 2,1053 & 19 &, 84293 \\
Mechanical Engineering & 2,2523 & 111 & 1,03764 \\
Architecture & 2,5172 & 29 &, 93046 \\
Electrical and Electronics Eng. & 2,3058 & 103 & 1,11635 \\
Computer Engineering & 2,4868 & 38 & 1,11795 \\
International Relations & 2,1406 & 64 &, 87500 \\
Total & 2,2857 & 364 & 1,02622 \\
\hline
\end{tabular}

Table IX shows distribution of the mean scores in the "entertainment image." The mean scores of the "entertainment image" is at low level $(x=2,28)$. Students from Architecture Department have the highest score $(x=2,51)$, and students from English Language Teaching and International Relations have the lowest score $(x=2,1)$ in this factor.

TABLE X: DisTRIBUTION OF THE SCORES IN ACCOMODATION-FOOD

\begin{tabular}{lcrr}
\multicolumn{4}{c}{ IMAGE } \\
\hline DEPARTMENTS & Mean & N & Std. Deviation \\
\hline English Language Teaching & 3,1228 & 19 &, 73879 \\
Mechanical Engineering & 2,4535 & 111 &, 98657 \\
Architecture & 2,6437 & 29 &, 90383 \\
Electrical and Electronics Eng. & 2,5275 & 103 &, 97409 \\
Computer Engineering & 2,6228 & 38 &, 88759 \\
International Relations & 2,5104 & 64 &, 76282 \\
Total & 2,5522 & 364 &, 92446 \\
\hline
\end{tabular}

Table $\mathrm{X}$ shows distribution of the mean scores in the "accommodation-food image." The mean scores of the factor is at low level $(x=2,55)$. Students from English Language Teaching Department have the highest score $(x=3,12)$, and students from and Mechanical Engineering Department have the lowest score $(x=2,4)$ in this factor.

\section{RESULTS AND RECOMMENDATIONS}

This study showed that overall image of the university is at moderate level according to the students' perceptions. The image of the university according to the students' perceptions is "low" in the sublevel of entertainment image; "moderate" in the sublevels of quality image, social atmosphere image, general outlook and infrastructure image, sports image, program image, accommodation-food image, which explains the overall image of the university. Accordingly, Polat [17] found out that the organizational image perception of the students of Kocaeli University is moderate. In the sub-levels, the sports image and accommodation-food image were low, which is not in parallel with our research results. However, the other sublevels have similar image levels.

The results showed that the entertainment image has the lowest score; however, the other images are at moderate level according to the students' perceptions.

In the first factor, the students' perceptions on the quality image showed that the image is at moderate level. Moreover, the students from Electrical and Electronics Engineering have the highest score whereas the Architecture students have the lowest. High quality higher education institution 
means that it employs good staff who are expert in their fields. Those features attract more talented students and those talented students would raise the reputation of the university after they graduate and find good jobs. Therefore, the quality of the services provided to the students must be increased in order to convey a high quality institutional image.

In the second factor, the students' perceptions on the program image showed that the image is at moderate level. The students from English Language Teaching have the highest score whereas the International Relations students have the lowest. It can be deducted from the responses of the students that the university is not a leader institution in a particular field. The universities can enhance the program image by recruiting leader staff and increasing the quality of the education they provide.

In the third factor, the sports image, students' responses showed that the image is at moderate level. The students from Computer Engineering have the highest score whereas the International students have the lowest. The university has a relatively big sports center, which is surrounded by football fields, tennis courts, basketball fields and a climbing wall. Moreover, there are lots of sport clubs. Having a moderate level of sports image can be explained by the lack of advertisement of those facilities. As the population of this study includes the students in their first year, they may not have been informed about those facilities Therefore, the sports facilities must be advertised to the students at the beginning of their education.

In the fourth factor, the students' perceptions on the general outlook and physical infrastructure image, the responses showed that the image is at moderate level. The students' responses are at nearly the same level in this factor. When the students first come to the campus, the first thing they notice is the buildings and the facilities they see. The university has a big library in which the students can go online by their personal computers or they can use the computers provided by the university; and they can reach the international databases for their academic studies. Also, the faculties have computer rooms where they can go online and study. After the students start living in the campus, they compare the facilities on campus to the others they have seen or they have heard about. As a result, the image about the general outlook and the infrastructure emerges. Therefore, modernization of or having more modern physical outlook and the facilities, or publicizing those facilities would result in better image perceptions.

The social atmosphere image is at moderate level. In this factor, the opinions about the managers' attitudes, the attitudes towards different opinions and having democratic practices would form the image. For this reason, being sensitive to the social problems and being at the equal distance to different opinions would improve the image of the institution.

In the sixth factor, the entertainment image, the responses showed that the image is low. Some activities in the university campus like traditional game days or having concerts would create the entertainment image. It is seen that the university lacks those activities. Having those kinds of activities based on the students' expectations might be a good idea to improve this image.
Finally, the accommodation and food image is at low level. In this part, the image is created by the facilities like restaurants and hostels/dormitories and their quality-price comparisons. The university has no dormitories/hostels because those kinds of requirements are provided by the state. However, it has a student cafeteria, which provides lunch and dinner at a very reasonable price, and there are other private owned restaurants and cafes. Moreover, there is a student center with cafes and restaurants. It can be said that there are enough food facilities inside the campus. However, having a moderate level of food and accommodation image can be explained by the prices that the students may think a bit high. As Nguyen and Leblanc [24] stated the price is one of the factors that construct the image.

The effects of image on people vary because it reflects the prestige of the organization or the people. For example, people feel more satisfied if they belong to a group that has a positive image in society [16], [25]. Therefore, being a member of an organization with a positive image would affect the students in a positive way. But as the students' overall image perception of the university is at moderate level, the factors affecting the image should be improved. As Palacio et al. [16] indicate, the managers must consider the overall image of the university and develop policies to improve. One of the ways is advertising the facilities in the organization.

In Turkey, the process of image building or communication of the image to the target society is not managed well, and the students cannot get enough information about the universities because they do not publicize their image well [26]. This study only aimed to find out the organizational image of ESOGU by the views of students who are studying at the Department of Foreign Languages. Therefore, it doesn't show the views of all the students at this university. However, it is recommended that the image of the first year students and the ones at their final year can be gathered and compared. Perceptions are framed by the actual experiences and by the biases as Spector [10] indicates. The students' perceptions may affect the others who would like to study at this university. Moreover, as Kazoleas et al. [27] state the universities should communicate their image to their internal stakeholders. Therefore, creating a good image in the minds of current students would mean investing the future of the institution [26].

\section{CONCLUSION}

As the images are created by different factors, the managers of an organization should consider those factors in order to develop a better image in the minds of target population. Having a positive image would mean that the organization is a prestigious one. As a result, it would attract better staff and students, which would increase the prestige and overall image by graduating high-qualified people. Moreover, the students studying at the university would influence the others with their comments, so their image perceptions would have an impact on the others. To sum up, the overall image perception of the stakeholders (the students in this study) must be improved for the future of an 
organization.

\section{APPENDIX}

\section{Appendix I: Organizational Image Instrument Items}

\section{Quality image}

The university is a high quality university.

The university has got a unique "school spirit".

The university staff focussed on quality education.

The university has got programmes that will ensure high quality graduates. The university provides comprehensive and good service for its students. The university has the responsibility to provide quality service to the public.

The academic programmes in the university are good.

The academic staff of the university are expert in their field.

The university prepares the students for the work life.

\section{Program image}

The university is well-known by its programmes on social sciences and humanities.

The university has got its reputation in the fields of science and health sciences.

The university is well-known by its education on vocational-technical fields.

The university is known by its programmes on teacher education.

The university is a usual and silent one which is not specialized in any field. The university is well-known by its staff who conduct pioneer/leading researches on their fields.

The university is well-known by its arts programmes.

The university is well-known by its physical education and sports programmes.

\section{Sports image}

The university has got quite good sports programmes.

The university has got adequate sports facilities.

The university has got good sports teams.

\section{General outlook and physical infrastructure image}

The university is like a city centre because it has clubs and cafes.

The university has got adequate infrastructure in the fields of computer, the Internet and other technical fields.

The university has got enough facilities in terms of library, fine arts programmes, music, arts and theatre.

The buildings in the campus are modern.

The campus outlook/design is good.

The university has got a bigger campus compared to other universities.

\section{Social atmosphere image}

The managers of the university acts legally and ethically.

The university is active in social and political issues.

The university treats equally to different political ideas and gives

opportunities to them.

The university is a known by its democratic practices

\section{Entertainment image}

The university is well-known by its "entertainment".

The university has entertainment/game day traditions.

Accommodation and food image

Life expenses in the university are cheaper in comparison to other state-run universities.

The university good in terms of food facilities.

The university good in terms of accommodation facilities.

\section{REFERENCES}

[1] J. Marconi, Image Marketing: Using Public Perceptions to Attain Business Objectives, NTC Business Books, 1996.

[2] M. Schuler, "Management of the organizational image: a method for organizational image configuration," Corporate Reputation Review, vol. 7, no. 1, pp. 37-53, January 2004

[3] A. Easton, "Corporate style versus corporate image," Journal of Marketing Research,vol. 3, no.2, pp. 168-174, May 1966.

[4] D. A. Gioia, A. L. Hamilton, and S. D. Patvardhan, "Image is everything: Reflections on the dominance of image in modern organizational life," Research in Organizational Behavior, vol. 34: pp. 129-154, February 2014

[5] J. R. Gregory, Marketing Corporate Image: The Company As Your Number one Product, NTC Business Books, 1991.

[6] H. Barich, and P. Kotler, "A framework for marketing image management," Sloan management review, vol. 32 no. 2, pp. 94-104, January 1991.

[7] Y. Bulduklu, İmaj Yönetimi: Yaklaşımlar, Taktikler, stratejiler, İstanbul: Literatürk Academia, 2015.
[8] J. E. Dutton and J. M. Dukerich, "Keeping an eye on the mirror: Image and identity in organizational adaptation," Academy of Management Journal, vol 34, no: 3, p. 517-554, September 1991.

[9] Ö. Bakan, Kurumsal Imaj, Konya: Tablet Kitabevi, 2005.

[10] A. J. Spector, "Basic dimensions of the corporate image," The Journal of Marketing, vol. 25, no. 6, pp. 47-51, October 1961.

[11] J. Lemmink, A. Schuijf, and S. Streukens, "The role of corporate image and company employment image in explaining application intentions," Journal of Economic Psychology, vol, 24, no. 1, pp. 1-15, February 2003.

[12] N. Nguyen, and G. Leblanc, "Corporate image and corporate reputation in customers' retention decisions in services," Journal of retailing and Consumer Services, vol, 8, no. 4, pp. 227-236, July 2001.

[13] E. R. Gray and J. M. Balmer, "Managing corporate image and corporate reputation," Long Range Planning, vol. 31, no. 5, pp. 695702, October 1998

[14] S. Frandsen, "Organizational Image, Identification, and Cynical Distance Prestigious Professionals in a Low-Prestige Organization," Management Communication Quarterly, vol. 26, no. 3, pp. 351-376, August 2012.

[15] H. Alves and M. Raposo, "The influence of university image on student behaviour," International Journal of Educational Management, vol. 24, no. 1, pp. 73-85, 2010.

[16] B. A. Palacio, D. G. Meneses, and P. P. J. Pérez, "The configuration of the university image and its relationship with the satisfaction of students," Journal of Educational Administration, vol. 40, no. 5, pp 486-505, 2002.

[17] S. Polat, "Organizational image of Kocaeli University for university students," Education and Science, vol. 36, no. 160, p. 105-119, 2011.

[18] Ö. Silsüpür, "Üniversite Öğrencilerinin Gözünde İstanbul Üniversitesi'nin İmaj1," Gumushane University e-Journal Of Faculty Of Communication, vol. 3, say1. 1, March 2015.

[19] L. Örer, "Kahramanmaras sütçü imam Üniversitesi'nin kurumsal imajının öğrenciler açısından ölçülmesi üzerine bir alan çalışması," MA Thesis, Kahramanmaras Sutçu Imam University, Kahramanmaraş, 2006.

[20] Y. Cerit, "Organizational image perceptions of the university by undergraduate students of school of education," Educational Administration: Theory and Practice, vol. 12, no. 3, pp. 343-365, Summer 2006

[21] G. Şişli and K. Sevinç, "Kurum kültürü ve kurumsal imaj ilişkisi: Devlet ve vakıf üniversiteleri üzerinde bir uygulama," Erciyes Üniversitesi İktisadi ve İdari Bilimler Fakültesi Dergisi, no. 41, pp. 165-193, January-June 2013.

[22] ESOGU. Öğrenci sayıları (number of students). [Online]. Available: http://oidb.ogu.edu.tr/Sayfa/Index/69/2015-2016-ogretim-yili

[23] J. Bartlett, J. Kortlik, and C. Higgins, "Determining appropriate sample size for survey research," A Journal of Information Technology Learning And Performance, vol. 19, no. 1, pp. 43-50, Spring 2001

[24] N. Nguyen and G. LeBlanc, "Image and reputation of higher education institutions in students' retention decisions," International Journal of Educational Management, vol. 15, no. 6, pp. 303-311, 2001.

[25] V. K. Lim, T. S. Teo, and S.K. See, "Perceived job image among police officers in Singapore: Factorial dimensions and differential effects," The Journal of Social Psychology, vol. 140, no. 6, pp. 740750, April 2000

[26] G. S. Atabek and Ü. Atabek, "Images of Turkish universities: A study on university print advertisements," Education and Science, vol. 40, No. 180, pp. 155-168, 2015.

[27] D. Kazoleas, Y. Kim, and M. Anne Moffitt, "Institutional image: A case study," Corporate Communications: An International Journal, vol. 6, no. 4, pp. 205-216, 2001.

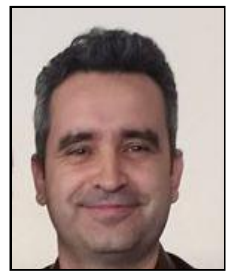

Özcan Doğan was born in Manisa, Turkey in 1977. He got the master of arts in educational administration from Eskisehir Osmangazi University in 2009. He is a PhD student in Anadolu University in the field of educational administration, evaluation, planning and economics.

He has been an English lecturer at Eskisehir Osmangazi University since 1999.

His research interests include teacher education, image management, occupational image and corporate image. 